\title{
Work Experience as a Moderating Variable of the Influence of Intelligence on the Performance of Malang Government Employees
}

\author{
Tri Yulianto ${ }^{1}$, Siswanto ${ }^{1}$, Masyhuri ${ }^{2 *}$ \\ ${ }^{1}$ Faculty of Economics, State Islamic University of Maulana Malik \\ Ibrahim, Malang, Indonesia. \\ ${ }^{2}$ Islamic University of Malang, Indonesia \\ *Corresponding author:22002081017@unisma.ac.id
}

\author{
Article history \\ Received, 10 Octo 2021 \\ Revised 1, 24 Nov 2021 \\ Accepted, 27 Dec 2021
}

\begin{abstract}
This study aims to see the effect of intellectual intelligence and emotional intelligence on employee performance with experience as a moderating variable. This research was conducted at the Public Works Department of Malang City. The type of research used is a quantitative approach research model using data in the form of numbers. The sample used as many as 122 respondents with the technique of taking census research. Two regression tests were carried out; the first was the independent variable test without the moderating variable, the second was carried out on all independent variables and the moderating variable. This study indicates that in the first test simultaneously or partially, all intellectual and emotional intelligence influence employee performance. After being moderated with work experience variables in the second test, intellectual and emotional intelligence variables become insignificant on employee performance. Thus, the moderating variable of work experience is only a moderating predictor variable.
\end{abstract}

Keywords: Intellectual intelligence, Emotional intelligence, employee performance.

Cite this article:

Tri Yulianto ${ }^{1 *}$, Siswanto ${ }^{1}$, Masyhuri $^{2}$

Yulianto, T., Siswanto., Masyhuri., (2021). Work Experience as a

Moderating Variable of the Influence of Intelligence on the

Performance of Malang Government Employees, Jurnal Al-Qardh,

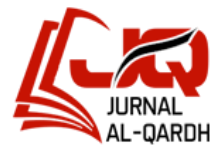

pISSN: $2354-6034$

eISSN: $2599-0187$

6(2), 62-75. https://doi.org/10.23971/jaq.v6i2.3268

\section{Introduction}

The problem of human resources is still in the spotlight and foundation for companies and agencies to survive in the era of globalization. Good or bad human resources in the company will affect the success of the company as a whole. ${ }^{1}$ Therefore, every employee in the company must have qualified competencies so that organizational activities run well. Human resources are a gift given by Allah SWT to humans who make humans more perfect than other creatures. The statement is found in a snippet of the Qur'anic verse, which means "...and on earth, there are signs (of Allah's power) for people who believe, and (also) in yourself. Then did you not notice?".

\footnotetext{
1Yuniningsih, (2002), Membangun Komitmen dan Menciptakan Kinerja Sumber Daya Manusia Untuk Memperoleh Keberhasilan Perusabaan, Fokus Ekonomi Vol.1, No.1 April 2002.
} 


\section{Work Experience as a Moderating Variable of the Influence of Intelligence on the Performance of Malang Government Employees}

A piece of the verse above shows that humans have resources, one of which is intelligence. Other creatures have limited intelligence, whereas humans do not. Human intelligence can understand all the phenomena of life in depth. With intelligence, humans can also know an event and then take wisdom and lessons from it. Scientists are now increasingly aware of how important it is for humans to turn back to understand themselves more deeply. Several existing studies suggest that intellectual ability is an apparatus of mental abilities essential in carrying out tasks or work.

In his research, Caruso stated that intellectual ability as measured by IQ is still essential in work success, "In fact, many psychologists still believe that IQ is the single best predictor of workplace success". ${ }^{2}$ Work is not only actions to carry out work but also intelligence in analyzing something. Intellectual intelligence plays a role when a worker uses his analytical and cognitive abilities to solve problems in completing work to get the best results. Nevertheless, Daniel Goleman has a different opinion than the most considerable abilities that affect a person's success in work: empathy, self-discipline, and initiative. Through his research, Goleman suggests that Emotional Quotient (EQ) contributes 80\% of a person's success factor, while the other $20 \%$ is determined by Intelligence Quotient (IQ). ${ }^{3}$ Current employee performance relies not only on increasing intelligence (IQ) and emotional intelligence (EQ) capacity because the education and experience of each individual also support the quality of successful performance. Thoha expresses that the emergence of intelligence is a person's intelligence that is brought from birth and the influence of education and experience. ${ }^{4}$ Work experience provides a lot of expertise and work skills. On the other hand, limited work experience results in lower levels of expertise and skills. The classic proverb says the experience is a good teacher (experience is the best of teacher). Work experience is a person's principal capital to enter a specific field. Based on performance, experience with the work in question, age, and gender are determined. In this way, the researcher is pleased to add experience as a moderating variable (a variable that strengthens or weakens the relationship between the independent and dependent variables). ${ }^{5}$

The performance of an employee will determine the performance of the organization where he works. The tasks of each employee as a whole will impact the organization's activities. Thus, the performance development of each employee must receive intensive attention because employee performance is constructive for the company in achieving short-term and long-term goals. Employee performance is the ultimate goal and is a way for various managers to ensure that employee activities and the resulting output follow organizational goals, thus making employees who are members of an organization bring a set of desires, needs, desires and past experiences that combine to formwork expectations. ${ }^{6}$ The Department of Public Works, Housing and Building Supervision of the city of Malang have the task of carrying out essential authorities in irrigation and spatial planning. Bina Marga in the development of infrastructure in the city of Malang, therefore

${ }^{2}$ Carruso (1999) Caruso, D, R, 1999, Applying The Ability Model Of Emotional Intelligence To The World Of Work, http://cjwolfe.com/article.doc, 16 January 2016.

${ }^{3}$ Goleman, D. (2000). Kecerdasan Emosi:Mengapa Emotional Intelligence Lebih Tinggi Daripada IQ, Alih Bahasa : T. Hermany,Jakarta: PT. Gramedia Pustaka Utama.

${ }^{4}$ Armansyah. (2006). Intelegency Quotient, Emotional Quotient, dan Spiritual Quotient dalam Membentuk Perilaku Kerja. Jurnal Ilmiah Manajemen \& Bisnis,

${ }^{5}$ Luthans,F. (2006).Perilaku Organisasi 10th. Edisi Indonesia.Yogyakarta: Penerbit ANDI.

${ }^{6}$ Davis, Keith dan John W. Newstrom, (1985). Perilaku Dalam Organisasi, Jilid I, Edisi 7, Jakarta: Erlangga. 
the reason for researchers to research the influence of intellectual intelligence and emotional intelligence on employee performance with experience as moderating variable because the operation of the Public Works Department is closely related to abilities involving intellectual intelligence and emotional intelligence that will affect performance.

In operational activities, technical abilities require intellectual intelligence capabilities to solve problems in work to be faced. Besides that, it also requires emotional intelligence to identify themselves, motivate, empathize and have good social skills to work with colleagues. In addition, there are several news reports posted by Media EHI (Indonesian Legal Entity) in 2013 that the Performance of the Public Works Department in the infrastructure development of the city of Malang seems careless and unplanned as a function of the DPUPB (Public Works Department, Housing Office and Building Supervision) Malang city. ${ }^{7}$ Several previous studies on intellectual intelligence and its effect on employee performance have been carried out by ${ }^{89}$ and ${ }^{10}$ who agree that intellectual intelligence can affect employee performance. Furthermore, research related to emotional intelligence in improving employee performance has been carried out by ${ }^{11}{ }^{12}$ and ${ }^{13}$ who agree that emotional intelligence can improve employee performance.

At the end of December 2014, there was good news regarding the Performance of the Malang City Public Works, Housing and Building Supervision Service so that it won the 2nd best award at the national level. In this case, there are indirectly efforts to improve the performance contained in the DPUPB so that the city of Malang deserves to be awarded second place after Surabaya as the "Best Metropolitan City" (www. entities Hukum.com). Keeping in mind that operational work activities in the Public Works Department often interact directly with the community and from some of the above explanations, the researchers intend to conduct a study entitled "The Effect of Intellectual Intelligence and Emotional Intelligence on Employee Performance with Work Experience as Moderating Variables (case study at the Public Works Department)Housing and Building Supervision of Malang City)".

\section{Method}

This study uses a quantitative approach with primary data collected through research questionnaires that have been tested for validity and reliability ${ }^{14}$. The research was conducted at the Office of the Public Works, Housing and Building Supervision Office of

\footnotetext{
7 (http:/ / entitas-law-indonesia.blogspot.co.id)

${ }^{8}$ Fareed, M. Z., Su, Q., \& Awan, A. A. (2021). The effect of emotional intelligence, intellectual intelligence and transformational leadership on project success; an empirical study of public projects of Pakistan. Project Leadership and Society, 2, 100036.

${ }^{9}$ Erickson, S. L., Salekin, K. L., Johnson, L. N., \& Doran, S. C. (2020). The predictive power of intelligence: Miranda abilities of individuals with intellectual disability. Law and human behavior, 44(1), 60.

${ }^{10}$ Lie, D., Simatupang, S., Harini, S., Dharma, E., \& Sudirman, A. (2021). Teacher Performance in Terms of The Aspects of Intellectual Intelligence, Emotional Intelligence and Spiritual Intelligence. JPI (Jurnal Pendidikan Indonesia), 10(2).

11 Supriyanto, A. S., Ekowati, V. M., \& Masyhuri, M. (2019). The relationship among spiritual intelligence, emotional intelligence, organizational citizenship behaviour, and employee performance. Etikonomi, 18(2), 249-258.

12 Wu, Y., Lian, K., Hong, P., Liu, S., Lin, R. M., \& Lian, R. (2019). Teachers' emotional intelligence and selfefficacy: Mediating role of teaching performance. Social Behavior and Personality: an international journal, 47(3), 1 10.

13 Rezvani, A., Barrett, R., \& Khosravi, P. (2019). Investigating the relationships among team emotional intelligence, trust, conflict and team performance. Team Performance Management: An International Journal.

14 Arikunto (2002). Prosedur Penelitian, Jakarta: Rineka Cipta.
} 


\section{Work Experience as a Moderating Variable of the Influence of Intelligence on the Performance of Malang Government Employees}

Malang City as many as 122 employees who were used as respondents. The sampling technique is the census or the entire population is used as the research sample. Before testing the hypothesis, the validity and reliability of the research instrument was tested. Followed by testing the classical assumptions in the form of normality, multicollinearity and heteroscedasticity tests. Based on testing using SPSS assistance, it can be concluded that in this study the instrument used was valid and reliable, then the classical assumption test had met or the regression model had met all classical assumption tests so that the research was feasible to proceed to hypothesis testing.

This study uses 4 variables including intellectual intelligence, emotional intelligence and work experience as independent variables, then employee performance as the dependent variable. Furthermore, each variable was measured using a Likert scale with 5 answers from 1 strongly disagree to strongly agree with number 5 . Hypothesis testing using moderated regression analysis. Moderated Regression Analysis (MRA) is a special application of regression where the regression equation contains elements of interaction between one or more independent variables on the dependent ${ }^{15}$. To test the effect of intellectual intelligence (IQ) and emotional intelligence (EQ) on employee performance which is moderated by experience, Moderated Regression Analysis (MRA) is used with the help of SPSS version 16 program.

\section{Result and Discussion}

Respondents in the study, most of the respondents were male as many as 75 respondents $(61.5 \%)$, then female respondents were 47 respondents $(38.5 \%)$. Furthermore, respondents aged $41-50$ years were 45 respondents $(36.9 \%)$, and the least respondents were 20 respondents $(16.4 \%)$ aged $20-30$ years. Then most of the respondents' education was undergraduate graduates as many as 64 respondents $(52.5 \%)$, the next respondent was D3 graduates as many as 33 respondents $(27 \%)$ while the rest were high school graduates as many as 25 respondents $(20.5 \%)$. Finally, most of the respondents had a working period of $11-20$ years, as many as 47 respondents $(38.5 \%)$, then the next respondent had a service period of less than 10 years, of which 42 respondents $(34.4 \%$ ), the rest 33 respondents $(27 \%)$ have more than 20 years of work experience. In more detail, the characteristics of the respondents are presented in table 1 below.

Tabel 1. Characteristics of Respondents

\begin{tabular}{|l|l|c|c|}
\hline Karakteristik & \multicolumn{1}{|c|}{ Item } & Frequency & Presentase (\%) \\
\hline Sex & Female & 47 & 38,5 \\
& Male & 75 & 61,5 \\
\hline Age & 20-30 Year & 20 & 16,4 \\
& 31-40 Year & 35 & 28,7 \\
& 41-50 Year & 45 & 36,9 \\
& >50 Year & 22 & 18,0 \\
\hline Education & Senior High & 25 & 20,5 \\
& School & & \\
& D3 & 33 & 27,0 \\
& S1 & 64 & 52,5 \\
\hline \multirow{2}{*}{ wength } & of & 42 & 34,4 \\
& 11-20 Year & 47 & 38,5 \\
& >20 Year & 33 & 27,0 \\
\hline
\end{tabular}

\footnotetext{
15 Ghozali, Imam, (2006). Aplikasi Analisis Multivariate Dengan Program SPSS (Edisi Kedua), Semarang: Badan Penerbit Universitas Diponegoro.
} 
Jurnal Al-Qardh, Vol.6, No.2, Desember 2021, hlm. 62-75

Validity and Reliability Test

Table 2. Validity Test

\begin{tabular}{|c|c|c|c|c|}
\hline Variabel & Item & $\mathbf{R}$ & Sig & Ket \\
\hline \multirow{11}{*}{$\begin{array}{l}\text { Intellectual } \\
\text { Intelligence }\left(\mathrm{X}_{1}\right)\end{array}$} & item 1 & 0,677 & 0,000 & Valid \\
\hline & item 2 & 0,805 & 0,000 & Valid \\
\hline & item 3 & 0,562 & 0,000 & Valid \\
\hline & Item 4 & 0,790 & 0,000 & Valid \\
\hline & item 5 & 0,843 & 0,000 & Valid \\
\hline & item 6 & 0,888 & 0,000 & Valid \\
\hline & item 7 & 0,767 & 0,000 & Valid \\
\hline & Item 8 & 0,670 & 0,000 & Valid \\
\hline & item 9 & 0,791 & 0,000 & Valid \\
\hline & item 10 & 0,859 & 0,000 & Valid \\
\hline & item 11 & 0,840 & 0,000 & Valid \\
\hline \multirow{22}{*}{$\begin{array}{l}\text { Emotional } \\
\text { Intelligence } \\
\left(\mathrm{X}_{2}\right)\end{array}$} & item 1 & 0,702 & 0,000 & Valid \\
\hline & item 2 & 0,784 & 0,000 & Valid \\
\hline & item 3 & 0,516 & 0,000 & Valid \\
\hline & Item 4 & 0,644 & 0,000 & Valid \\
\hline & item 5 & 0,764 & 0,000 & Valid \\
\hline & item 6 & 0,695 & 0,000 & Valid \\
\hline & item 7 & 0,788 & 0,000 & Valid \\
\hline & Item 8 & 0,731 & 0,000 & Valid \\
\hline & item 9 & 0,802 & 0,000 & Valid \\
\hline & item 10 & 0,689 & 0,000 & Valid \\
\hline & item 11 & 0,509 & 0,000 & Valid \\
\hline & item 12 & 0,558 & 0,000 & Valid \\
\hline & item 13 & 0,751 & 0,000 & Valid \\
\hline & item 14 & 0,727 & 0,000 & Valid \\
\hline & item 15 & 0,844 & 0,000 & Valid \\
\hline & item 16 & 0,729 & 0,000 & Valid \\
\hline & item 17 & 0,720 & 0,000 & Valid \\
\hline & item 18 & 0,730 & 0,000 & Valid \\
\hline & item 19 & 0,685 & 0,000 & Valid \\
\hline & item 20 & 0,628 & 0,000 & Valid \\
\hline & item 21 & 0,814 & 0,000 & Valid \\
\hline & item 22 & 0,870 & 0,000 & Valid \\
\hline \multirow{9}{*}{ Work experience $\left(\mathrm{X}_{3}\right)$} & Item 1 & 0,633 & 0,000 & Valid \\
\hline & Item 2 & 0,632 & 0,000 & Valid \\
\hline & Item 3 & 0,579 & 0,000 & Valid \\
\hline & Item 4 & 0,675 & 0,000 & Valid \\
\hline & Item 5 & 0,640 & 0,000 & Valid \\
\hline & Item 6 & 0,732 & 0,000 & Valid \\
\hline & Item 7 & 0,696 & 0,000 & Valid \\
\hline & Item 8 & 0,739 & 0,000 & Valid \\
\hline & Item 9 & 0,709 & 0,000 & Valid \\
\hline
\end{tabular}


Work Experience as a Moderating Variable of the Influence of Intelligence on the Performance of Malang Government Employees

\begin{tabular}{|l|c|c|c|c|}
\hline & Item 10 & 0,789 & 0,000 & Valid \\
\cline { 2 - 5 } & Item 11 & 0,686 & 0,000 & Valid \\
\hline & Item 1 & 0,700 & 0,000 & Valid \\
\cline { 2 - 5 } & Item 2 & 0,768 & 0,000 & Valid \\
\hline & Item 3 & 0,535 & 0,000 & Valid \\
\cline { 2 - 5 } & Item 4 & 0,644 & 0,000 & Valid \\
\cline { 2 - 5 } & Item 5 & 0,639 & 0,000 & Valid \\
\cline { 2 - 5 } & Item 6 & 0,736 & 0,000 & Valid \\
\cline { 2 - 5 } & Item 7 & 0,683 & 0,000 & Valid \\
\cline { 2 - 5 } & Item 8 & 0,713 & 0,000 & Valid \\
\cline { 2 - 5 } & Item 9 & 0,587 & 0,000 & Valid \\
\cline { 2 - 5 } & Item 10 & 0,645 & 0,000 & Valid \\
\cline { 2 - 5 } & Item 11 & 0,766 & 0,000 & Valid \\
\cline { 2 - 5 } & Item 12 & 0,603 & 0,000 & Valid \\
\cline { 2 - 5 } & Item 13 & 0,713 & 0,000 & Valid \\
\cline { 2 - 5 } & Item 14 & 0,768 & 0,000 & Valid \\
\cline { 2 - 5 } & Item 15 & 0,557 & 0,000 & Valid \\
\cline { 2 - 5 } & Item 16 & 0,714 & 0,000 & Valid \\
\cline { 2 - 5 } & Item 17 & 0,671 & 0,000 & Valid \\
\hline
\end{tabular}

Based on table 2 above, it can be seen that all question items on the Intellectual Intelligence variable have a probability value (sig) of less than 0.05 so that it can be said that all question items are valid. Furthermore, the reliability test is carried out as follows:

Table 3. Reliability Test

\begin{tabular}{|l|c|l|}
\hline \multicolumn{1}{|c|}{ Variables } & $\begin{array}{c}\text { Cronbach's } \\
\text { Alpha }\end{array}$ & Result \\
\hline Intellectual Intelligence $\left(\mathrm{X}_{1}\right)$ & 0,931 & Reliabel \\
\hline Emotional Intelligence $\left(\mathrm{X}_{2}\right)$ & 0,953 & Reliabel \\
\hline Work Experience $\left(\mathrm{X}_{3}\right)$ & 0,833 & Reliabel \\
\hline Performance $(\mathrm{Y})$ & 0,922 & Reliabel \\
\hline
\end{tabular}

Based on table 2 above, it can be seen that the questionnaire item has a Cronbach Alpha coefficient value greater than 0.6 so it can be said that the question instrument used in this study is reliable or reliable.

\section{Classic Assumption Test}

\section{Normality Test}

Table 4. Normality Test

\begin{tabular}{|l|l|l|l|}
\hline Regresi & Statistik Uji & Signifikansi & Keterangan \\
\hline Model 1 & 0,898 & 0,395 & Menyebar Normal \\
\hline
\end{tabular}

In the regression equation in this research model, a significance of 0.395 is obtained where the value obtained is smaller than $=0.05$. Because the significance value is smaller 
than $=0.05$, it is decided to reject $\mathrm{H} 0$ and conclude that the data is not normally distributed, so it can be concluded that the assumption of normality is met.

Multikolonierity Test

Table 5. Multikolinearity Test Result

\begin{tabular}{|l|l|c|c|}
\hline Regression & Independent Variables & VIF & Result \\
\hline \multirow{4}{*}{ Model 1} & Intellectual Intelligence $\left(\mathrm{X}_{1}\right)$ & 3,535 & Non Multikolinierity \\
\cline { 2 - 4 } & Emotional Intelligence $\left(\mathrm{X}_{2}\right)$ & 3,535 & Non Multikolinierity \\
\cline { 2 - 5 } & Work Experience $\left(\mathrm{X}_{3}\right)$ & 9,985 & Non Multikolinierity \\
\hline
\end{tabular}

Table 5 above shows that the VIF value is less than 10 so it can be concluded that in this research model there is no symptom of multicollinearity.

\section{Heteroskedastisity Test}

\section{Scatterplot}

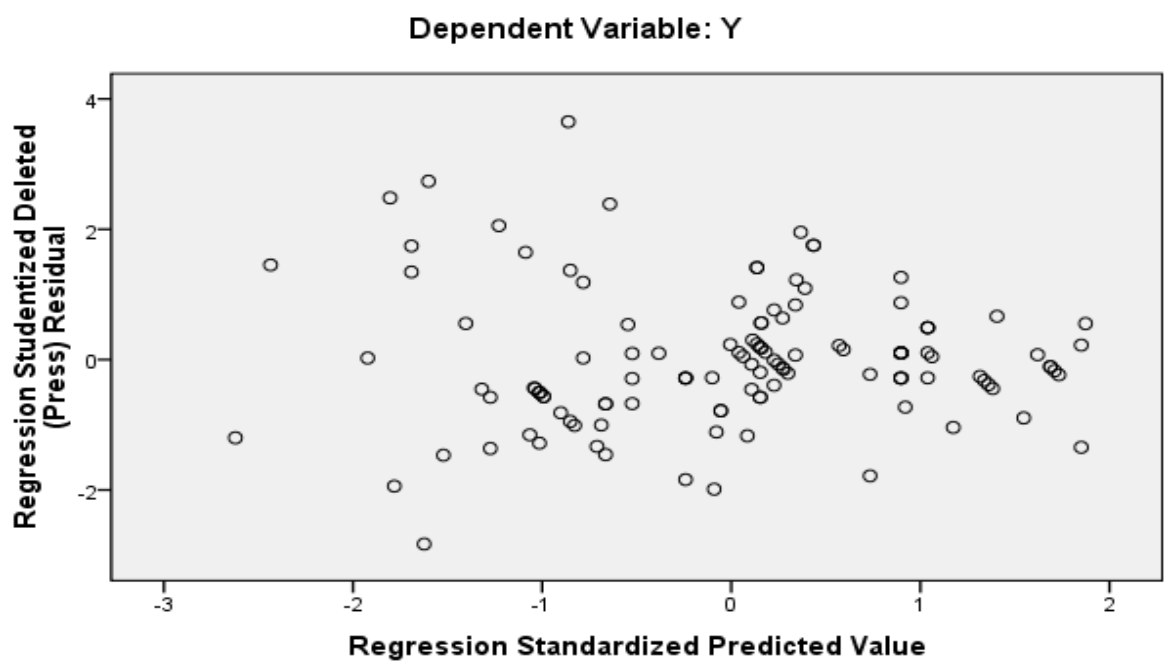

Figure 1. Scatterplot

Based on the picture above, it can be seen that the dots spread randomly. So it can be concluded that there is no heteroscedasticity and the assumption has been fulfilled.

\section{Hypothesis Testing}

In this study, the researcher wanted to examine the effect of intellectual intelligence (X1) and Emotional Intelligence (X2) on employee performance $(\mathrm{Y})$ with the experience variable (X3) as the moderating variable. Therefore, a moderating regression analysis was conducted between the intellectual intelligence variable (X1) and the emotional intelligence variable $(\mathrm{X} 2)$ on the employee performance variable $(\mathrm{Y})$ with the work experience variable (X3) as the moderating variable. From the results of data analysis, the results obtained as shown in table 4.1 below:

Table 6. Summary of Moderator Regression Analysis Results Model 1

\begin{tabular}{|l|l|l|l|l|l|}
\hline \multirow{2}{*}{$\begin{array}{l}\text { Regresi } \\
\text { Mode1 1 }\end{array}$} & Variables & B & T & Significant & Result \\
\cline { 2 - 6 } & Constant & 12.006 & & & \\
\cline { 2 - 6 } & $\mathrm{X}_{1}$ & 0.990 & 12.730 & 0.000 & Significant \\
\cline { 2 - 6 } & $\mathrm{X}_{2}$ & 0.159 & 3.408 & 0.001 & Significant \\
\hline
\end{tabular}


Work Experience as a Moderating Variable of the Influence of Intelligence on the Performance of Malang Government Employees

\begin{tabular}{|c|c|c|c|c|c|}
\hline & $\begin{array}{l}\alpha: \\
\text { R: } \\
\text { R Square: } \\
\text { F-Count: } \\
\text { Sig. F: }\end{array}$ & $\begin{array}{l}0.050 \\
0.942 \\
0.888 \\
472.081 \\
0.000\end{array}$ & & & \\
\hline \multirow{8}{*}{$\begin{array}{l}\text { Regresi } \\
\text { Model } 2\end{array}$} & Variables & B & $\mathbf{T}$ & Significant & Result \\
\hline & Constant & -19.406 & & & \\
\hline & $\mathrm{X}_{1}$ & 0.551 & 0.521 & 0.603 & Not Significant \\
\hline & $\mathrm{X}_{2}$ & 0.762 & 1.402 & 0.164 & Not Significant \\
\hline & $\mathrm{X}_{3}$ & 0.596 & 4.056 & 0.000 & Significant \\
\hline & $\mathrm{X}_{1} \mathrm{X}_{3}$ & 0.008 & 0.322 & 0.748 & Not Significant \\
\hline & $\mathrm{X}_{2} \mathrm{X}_{3}$ & -0.012 & -0.889 & 0.376 & Not Significant \\
\hline & $\begin{array}{l}\alpha: \\
\text { R: } \\
\text { R Square: } \\
\text { F-Count: } \\
\text { Sig. F: }\end{array}$ & $\begin{array}{l}0.050 \\
0.948 \\
0.899 \\
207.00 \\
0.000\end{array}$ & & & \\
\hline
\end{tabular}

Source: Processed data results, 2021

Based on the table above, the regression equation obtained is as follows:

\section{Model 1:}

$$
\mathrm{Y}=12.006+0.990 \mathrm{X}_{1}+0.159 \mathrm{X}_{2}(3)
$$

\section{Model 2:}

$$
Y=-19.406+0.551 X_{1}+0.762 X_{2}+0.596 X_{3}+0.008 X_{1} X_{3}+0.012 X_{2} X_{3}(4)
$$

Variable X1 has a regression coefficient of 0.990 , and a significant value of 0.000 is obtained. The statistical value of the significance test is more diminutive than $=0.05$. This test shows that $\mathrm{HO}$ is rejected, and it can be concluded that the intellectual intelligence variable $(\mathrm{X} 1)$ has a significant effect on the employee performance variable $(\mathrm{Y})$. Variable $\mathrm{X} 2$ has a regression coefficient of 0.159 , and a significant value of 0.001 is obtained. The statistical value of the significance test is more diminutive than $=0.05$. This test shows that $\mathrm{HO}$ is accepted, and it can be concluded that the emotional intelligence variable (X2) has a significant effect on the employee performance variable $(\mathrm{Y})$. Testing the simultaneous influence of intellectual intelligence (X1) and emotional intelligence (X2) obtained a significant value of 0.000 . The statistical value of the significance test is more diminutive than $=0.05$. This test shows that $\mathrm{H} 0$ is rejected, and it can be concluded that the variables of intellectual intelligence (X1) and emotional intelligence (X2) simultaneously have a significant effect on the employee performance variable $(\mathrm{Y})$.

Based on Table 5, the hypothesis testing of the moderator variable regression coefficient (X1X3) shows that the intellectual intelligence variable (X1) has a significance value of 0.748 . The statistical value of the significance test is more incredible than $=0.05$. This test shows that $\mathrm{H} 0$ is accepted, and it can be concluded that the intellectual intelligence variable (X1) after being influenced by the work experience moderator variable 
(X3) has no significant effect on the employee performance variable $(\mathrm{Y})$. The results show that by comparing the regression equations of models 1 and 2 , it is obtained that the work experience variable (X3) as a moderator has weakened the influence of the Intellectual Intelligence variable $(\mathrm{X} 1)$ on employee performance $(\mathrm{Y})$, i.e. from the previous significant effect to insignificant. In addition, based on Ghozali (2009), the type of moderation obtained in the regression equation model 2 is a moderator predictor. This moderator only acts as a predictor variable in the relationship model that is formed. The point obtained from the significance of the work experience variable (X3), which is significant at 0.000 and the X1X3 variable, which is also not significant, at 0.748 .

Based on Table 4.1, the hypothesis testing of the moderator variable regression coefficient (X2X3) shows that the emotional intelligence variable (X2) has a significance value of 0.376 . The statistical value of the significance test is more incredible than $=0.05$. This test shows that $\mathrm{H} 0$ is accepted, and it can be concluded that the emotional intelligence variable (X2) after being influenced by the work experience moderator variable (X3) has no significant effect on the employee performance variable $(\mathrm{Y})$. The result shows that by comparing the regression equations of models 1 and 2, it is obtained that the Work Experience variable (X3) as a moderator has weakened the influence of the Emotional intelligence variable $(\mathrm{X} 2)$ on employee performance $(\mathrm{Y})$, from the previous significant effect to insignificant. In addition, based on Ghozali (2009), the type of moderation obtained in the regression equation model 2 is a moderator predictor. This moderator only acts as a predictor variable in the relationship model that is formed. The result is obtained from the significance of the work experience variable (X3), significant at 0.000 , and the insignificant $\mathrm{X} 2 \mathrm{X} 3$ variable is 0.376 .

\section{Discussion}

\section{Intellectual Intelligence on Employee Performance}

From the results of research that has been done at the Department of Public Works, Housing and Building Supervision of Malang City with a sample of 122 respondents, there is a significant influence between intellectual intelligence on employee performance, with variable X1 having a regression coefficient of 0.990 and a significant value of 0.000 . The statistical value of the significance test is more diminutive than $=0.05$. This test shows that $\mathrm{H} 0$ is rejected, and it can be concluded that the intellectual intelligence variable (X1) has a significant effect on the Employee Performance variable (Y). The results of in-depth interviews conducted by researchers on informants regarding the differences between intellectual and emotional intelligence in a job. The question was addressed to Mrs Retno. With the first question, what is your opinion regarding the performance of someone who has high intellectual intelligence, then he answered:

"In work, someone who has high intelligence tends to have an individualistic nature because he feels he is capable of completing work well and quickly." (Retno, Informant 1).

As obtained from the results of interviews, someone who has intellectual intelligence tends to have the potential to complete work quickly and precisely without help from others. Many new opinions also prove that intelligence in weak-minded employees can also be educated more appropriately. The facts prove that the thinking power that has been educated from school shows better characteristics than children who do not go to school. In general, low IQ students have a low level of participation in learning, and vice versa, students with high IQ have high participation, which affects learning achievement. From some of the available evidence, psychologists still consider a person's intelligence, seen from the IQ score also expressed by Carusso, namely, In Fact, many psychologists still 


\section{Work Experience as a Moderating Variable of the Influence of Intelligence on the Performance of Malang Government Employees}

believe that IQ is the single best predictor of workplace success". ${ }^{16}$ Intellectual intelligence is intelligence related to cognitive processes such as thinking, connecting, and assessing or considering something or intelligence related to problem-solving strategies using logic. Someone with high intellectual intelligence can work quickly and precisely according to problem-solving strategies. Furthermore, the results of this study support previous research which states that intellectual intelligence can improve employee performance ${ }^{17} 1819$.

\section{Emotional Intelligence on Performance}

The study results prove that emotional intelligence influences performance, with the $\mathrm{X} 2$ variable having a regression coefficient of 0.159 , and a significant value of 0.001 is obtained. The statistical value of the significance test is more diminutive than $=0.05$. This test shows that $\mathrm{H} 0$ is accepted, and it can be concluded that the emotional intelligence variable (X2) has a significant effect on the employee performance variable (Y). Based on in-depth interviews conducted by researchers with informants regarding the differences between someone who has intellectual intelligence and emotional intelligence in a job. The question was addressed to Mrs Chalimah. With the first question: What is your opinion regarding the performance of someone who has high intellectual intelligence, then he answered:

"A person who has emotional intelligence tends to have mediocre abilities, but he wants to maintain communication with others even though his performance is a bit slower than an intellectual person, but someone who always maintains communication and cooperation with colleagues will be able to maximize productivity organization as a whole. Because with good teamwork (manage) the intensity of much work becomes lighter and can be resolved properly and quickly" (Chalima, Informant 2)

Someone with emotional intelligence tends to improve organizational performance because he always maintains cooperation and communication with colleagues and, therefore, can maximize productivity. Because with good teamwork (manage) the intensity of much work becomes light and can be resolved quickly and adequately." Daniel Goleman assumes that emotional intelligence accounts for $80 \%$ of a person's success factor, while Intelligence Quotient determines the other 20\%. With intelligence, humans try to prosper themselves and the quality of their lives. Islam highly recommends the importance of using reason. Countless verses of the Qur'an and the Hadith of the Prophet Muhammad encourage people always to think. Humans are not only told to think about themselves but are also called to think about the universe. In the context of Islam thinking about the universe will lead humans to awareness of the omnipotence of the Creator (Allah SWT).

\footnotetext{
${ }^{16}$ Carruso (1999) Caruso, D, R, 1999, Applying The Ability Model Of Emotional Intelligence To The World Of Work, http://cjwolfe.com/article.doc, 16 January 2016.

${ }^{17}$ Lee, C. W., \& Kusumah, A. (2020). Analysis of the influence of the emotional, intellectual and spiritual intelligence on employee performance with work motivation as a moderating variable. Management and Economics Review, 5(1), 51-67.

${ }^{18}$ Noegroho A, Wulansari N. Religiosity as a Moderation of the Effect of Intellectual and Spiritual Quotient on Employee Performance. MAJ [Internet]. 18Jun.2020 [cited 27Dec.2021];9(2):113-21.

${ }^{19}$ Santika, M., \& Rumengan, A. E. (2021). Determination of Emotional Intelligence, Intellectual Intelligence and Disciplined Working Spirit Working As a Variable Of Mediator Officer Performance at The Secretariat Areas Of Tanjung Pinang City. Zona Manajerial: Program Studi Manajemen (S1) Universitas Batam, 10(2), 15-26.
} 
Furthermore, the results of this study support previous research which states that emotional intelligence can improve employee performance 202122.

\section{Intellectual Intelligence and Emotional Intelligence on Performance}

The study results showed a simultaneous test of the influence of intellectual intelligence (X1) and emotional intelligence (X2). A significant value of 0.000 was obtained. The statistical value of the significance test is more diminutive than $=0.05$. This test shows that $\mathrm{HO}$ is rejected, and it can be concluded that the variables of intellectual intelligence (X1) and emotional intelligence (X2) simultaneously have a significant effect on the employee performance variable $(\mathrm{Y})$ if IQ elevates the function of thinking. EQ elevates the feeling function, IQ intelligence, and EQ will produce intellectual individuals who can solve problems wisely if both work in synergy..$^{23}$ As in Quraish Shihab's commentary, it is explained that what is meant by knowledge is that who is given knowledge. The verse divides the believers into two large groups, the first one is just believers and does good deeds, and the second is believers and does good deeds and has knowledge. The degree of this second group becomes higher, not only because of the value of the knowledge it bears but also its charity and teaching to other parties both orally, in writing and by example. ${ }^{24}$ Those who can rule this world are knowledgeable, quickly accumulate wealth, have a position, and are respected by people. Allah elevates the degree who believe and have knowledge if that knowledge is used to benefit the people. However, if the knowledge possessed is only used to harm others, this is not justified. So, faith and science must be in harmony and balance so that if he becomes a scholar, he becomes a knowledgeable scholar.

\section{Moderating Variable}

The results of the study show that the influence of intellectual intelligence is more remarkable than emotional intelligence. With intellectual intelligence regression coefficient of 0.990 while emotional intelligence regression coefficient of 0.159 . In addition, when viewed from the item scores in Table 4.10. The frequency distribution of respondents' answers to intellectual intelligence questions has the highest average score and is answered firmly by respondents on item 10, where item 10 is analytical and critical thinking in every decision making. Department of Public Works, Housing and Building Supervision of the City of Malang is a government agency engaged in infrastructure development so that it requires technical expertise that requires high intellectuals for in-depth analysis. However, it will be different if this research is carried out on companies that move in public relations, where emotional prowess is more necessary.

In the results of research, experience is a moderating variable with the name moderating predictor. This moderator only acts as a predictor variable in the relationship model that is formed. The result is obtained from the significance of the variable with a statistical significance test value greater than $=0.05$, the significant Work Experience (X3)

\footnotetext{
${ }^{20}$ MacCann, C., Jiang, Y., Brown, L. E. R., Double, K. S., Bucich, M., \& Minbashian, A. (2020). Emotional intelligence predicts academic performance: A meta-analysis. Psychological Bulletin, 146(2), 150-186. https://doi.org/10.1037/bul0000219

21 Ataullah Kiani, Delin Yang, Usman Ghani, Mathew Hughes. (2021) Entrepreneurial passion and technological innovation: the mediating effect of entrepreneurial orientation. Technology Analysis \& Strategic Management 0:0, pages 1-14.

22 Hamid, P. A., Suriansyah, A., \& Ngadimun, N. (2019). The Relationship between Interpersonal and Emotional Intelligence on Teacher Performance. Journal of K6 Education and Management, 2(1), 71-77. https://doi.org/10.11594/jk6em.02.01.10

${ }^{23}$ Dwi Sunar Prasetyono. (2010). Tes IQ dan EQ Plus!.Jogjakarta: Buku Biru.

${ }^{24}$ M. Quraish Shihab. (2002). Tafsir Al-Misbah, Vol. V, Jakarta: Lentera Hati.
} 


\section{Work Experience as a Moderating Variable of the Influence of Intelligence on the Performance of Malang Government Employees}

variable is 0.000 , the insignificant $\mathrm{X} 1 \mathrm{X} 3$ variable is 0.748 , and the insignificant $\mathrm{X} 2 \mathrm{X} 3$ variable is 0.376 . This test shows that $\mathrm{H} 0$ is accepted.

This case describes that intellectual intelligence after being influenced by the moderator variable work experience has no significant effect on the employee performance variable. As a moderator, the work experience variable has weakened the influence of the intellectual intelligence variable on employee performance and the emotional intelligence variable. The moderator variable, work experience, has no effect significant effect on employee performance variables and work experience variables as moderators have weakened the influence of emotional intelligence variables on employee performance, from the previous significant effect to insignificant. Work experience is a person's principal capital to enter a specific field. The company usually prioritizes workers with sufficient experience because experienced workers are more qualified in carrying out the work. The company can be employed according to the provisions of the company's request. Besides that, companies only need to provide training that does not take much time and money, but workers who only rely on their educational background and degree are not necessarily able to do the tasks and jobs assigned to them quickly because the theory that has been obtained from the education bench is sometimes different from the practice in the field of work. ${ }^{25}$ So if the experience is used as a moderating variable, it will weaken the intelligence variable, but good work experience affects good work results. It is proven that the experience variable has a regression coefficient level of 0.596 with a sig level. 0.000 with a statistical value of Significance Test $=0.05$.

\section{Conclusion}

The results of hypothesis testing provide empirical evidence that intellectual intelligence and emotional intelligence partially have a significant effect on employee performance. Intellectual intelligence and emotional intelligence simultaneously have a significant effect on employee performance. Intellectual and emotional intelligence have no significant effect on employee performance, with experience as a moderating variable. It turns out that intellectual intelligence and emotional intelligence positively affect employee performance, either partially tested or tested simultaneously. Work experience also has a positive influence on employee performance. However, after work experience is used as a moderator variable between intellectual intelligence variables of emotional intelligence on employee performance, it will weaken the influence of intellectual intelligence and emotional intelligence on employee performance which started significantly became insignificant in such cases the experience variable was a moderating predictor variable. This is because the Public Works Department has routine work, so that experience is needed to carry out particular jobs that require expertise. Work experience is a person's principal capital to enter a specific field, and experienced workers are more qualified in carrying out their work. Workers who only rely on their educational background and degree are not necessarily able to do the tasks and jobs assigned to them quickly because the theory What has been obtained from the education bench is sometimes different from the practice in the field of work.

\footnotetext{
${ }^{25}$ Siswanto Sastrohadiwiryo, (2002), Manajemen Tenaga Kerja Indonesia Pendekatan Administratif dan Operasional, Jakarta: Bhumi Aksara.
} 


\section{References}

Arikunto (2002). Prosedur Penelitian, Jakarta: Rineka Cipta.

Armansyah.(2006). Intelegency Quotient, Emotional Quotient, dan Spiritual Quotient Dalam Membentuk Perilaku Kerja. Jurnal Ilmiah Manajemen \& Bisnis.

Ataullah Kiani, Delin Yang, Usman Ghani, Mathew Hughes. (2021) Entrepreneurial passion and technological innovation: the mediating effect of entrepreneurial orientation. Technology Analysis \& Strategic Management 0:0, pages 1-14.

Carruso (1999) Caruso, D, R, 1999, Applying The Ability Model Of Emotional Intelligence To The World Of Work, http://cjwolfe.com/article.doc, 16 January 2016.

Davis, Keith dan John W. Newstrom, (1985).Perilaku Dalam Organisasi, Jilid I, Edisi 7, Jakarta: Erlangga.

Dwi Sunar Prasetyono. (2010). Tes IQ dan EQ Plus!.Jogjakarta: Buku Biru.

Erickson, S. L., Salekin, K. L., Johnson, L. N., \& Doran, S. C. (2020). The predictive power of intelligence: Miranda abilities of individuals with intellectual disability. Law and buman behavior, 44(1), 60 .

Fareed, M. Z., Su, Q., \& Awan, A. A. (2021). The effect of emotional intelligence, intellectual intelligence and transformational leadership on project success; an empirical study of public projects of Pakistan. Project Leadership and Society, 2, 100036.

Goleman, D.(2000). Kecerdasan Emosi :Mengapa Emotional Intelligence Lebih Tinggi Daripada IQ, Alih Bahasa : T. Hermany,Jakarta: PT. Gramedia Pustaka Utama.

Ghozali, Imam, (2006). Aplikasi Analisis Multivariate Dengan Program SPSS (Edisi Kedua),Semarang: Badan Penerbit Universitas Diponegoro.

Hamid, P. A., Suriansyah, A., \& Ngadimun, N. (2019). The Relationship between Interpersonal and Emotional Intelligence on Teacher Performance. Journal of K6 Education and Management, 2(1), 71-77. https://doi.org/10.11594/jk6em.02.01.10

Lee, C. W., \& Kusumah, A. (2020). Analysis of the influence of the emotional, intellectual and spiritual intelligence on employee performance with work motivation as a moderating variable. Management and Economics Review, 5(1), 51-67.

Lie, D., Simatupang, S., Harini, S., Dharma, E., \& Sudirman, A. (2021). Teacher Performance in Terms of The Aspects of Intellectual Intelligence, Emotional Intelligence and Spiritual Intelligence. JPI (Jurnal Pendidikan Indonesia), 10(2).

Luthans,F. (2006). Perilaku Organisasi 10th. Edisi Indonesia.Yogyakarta: Penerbit ANDI.

MacCann, C., Jiang, Y., Brown, L. E. R., Double, K. S., Bucich, M., \& Minbashian, A. (2020). Emotional intelligence predicts academic performance: A meta-analysis. Psychological Bulletin, 146(2), 150-186. https://doi.org/10.1037/bul0000219

M. Quraish Shihab. (2002). Tafsir Al-Misbah, Vol. V, Jakarta: Lentera Hati.

Rezvani, A., Barrett, R., \& Khosravi, P. (2019). Investigating the relationships among team emotional intelligence, trust, conflict and team performance. Team Performance Management: An International Journal.

Santika, M., \& Rumengan, A. E. (2021). Determination Of Emotional Intelligence, Intellectual Intelligence and Disciplined Working Spirit Working As a Variable Of Mediator Officer Performance at The Secretariat Areas Of Tanjung Pinang City. Zona Manajerial: Program Studi Manajemen (S1) Universitas Batam, 10(2), 15-26.

Siswanto Sastrohadiwiryo, (2002), Manajemen Tenaga Kerja Indonesia Pendekatan Administratif dan Operasional, Jakarta: Bhumi Aksara. 
Work Experience as a Moderating Variable of the Influence of Intelligence on the Performance of Malang Government Employees

Supriyanto, A. S., Ekowati, V. M., \& Masyhuri, M. (2019). The relationship among spiritual intelligence, emotional intelligence, organizational citizenship behaviour, and employee performance. Etikonomi, 18(2), 249-258.

Wu, Y., Lian, K., Hong, P., Liu, S., Lin, R. M., \& Lian, R. (2019). Teachers' emotional intelligence and self-efficacy: Mediating role of teaching performance. Social Behavior and Personality: an international journal, 47(3), 1-10.

Yuniningsih, (2002), Membangun Komitmen dan Menciptakan Kinerja Sumber Daya Manusia Untuk Memperoleh Keberhasilan Perusahaan, Fokus Ekonomi Vol.1, No.1 April 2002.

(http:/ / entitas-law-indonesia.blogspot.co.id) 